\title{
Mule deer and elk foraging preference for 4 sage- brush taxa
}

\author{
CARL L. WAMBOLT
}

Author is professor, Department of Animal and Range Sciences, Montana State University, Bozeman, Mont. 59717.

\begin{abstract}
A 10 year study under natural winter conditions at 2 sites tested the hypothesis that mule deer (Odocoileus hemionus hemionus) and elk (Cervus elaphus nelsoni) forage equally on 4 sagebrush (Artemisia L.) taxa. Each year approximately 2,500 available leaders on 244 plants on the Northern Yellowstone Winter Range were examined for browsing. Browsing levels increased with winter severity, reaching $91 \%$ of leaders browsed for mountain big sagebrush (A. tridentata ssp. vaseyana [Rydb.] Beetle), the preferred taxon $(P \leq 0.05)$ that averaged 56.1\% at the 2 sites. Wyoming big sagebrush (A.t. ssp. wyomingensis Beetle and Young) was narrowly preferred $(38.6 \%)$ over basin big sagebrush (A.t. Nutt. ssp. tridentata) (30.3\%). Black sagebrush ( $A$. nova Nels.) was least preferred (17.0\%). Differences in preference among taxa were smallest during the severest winters when more elk were present thereby increasing total sagebrush utilization. Mule deer diets averaged $\mathbf{5 2 \%}$ sagebrush over the study. Many sagebrush plants were damaged and even killed by heavy browsing during the study. Promoting sagebrush productivity should be a management objective on similar winter game ranges.
\end{abstract}

Key Words: Artemisia tridentata, Artemisia nova, Odocoileus hemionus, Cervus elaphus, foraging behavior, preference, Yellowstone National Park

The ecological implications and forage relationships of common range shrubs are often over simplified in natural resource management decision making. Probably nowhere are these relationships more important than with the sagebrush (Artemisia L.) taxa which occur on an estimated 109 million ha in the western United States (Beetle 1960). Consideration of sagebrush ecology, including forage values, is a necessity for judicious range management.

Neither the importance of sagebrush taxa as forage, nor the effects of foraging on them are presently appreciated by many resource managers. Welch and McArthur (1979) cited the aggressive, productive, and persistent nature of big sagebrush (Artemisia tridentata Nutt.) as important characteristics of a range forage plant. It is these characters plus outstanding winter nutritional quality that justifies a breeding and selection program aimed at improving the forage values of the sagebrush complex (Welch and Wagstaff 1992).

Research was funded by the Montana Agricultural Experiment Station (J-3027). Manuscript accepted I8 Nov. 1995.
Several relatively short term studies, often conducted under artificial conditions with tame animals on planted sites, have determined preference ratings of herbivores for a number of sagebrush taxa (Scholl et al. 1977, Sheehy and Winward 1981, Welch et al. 1981, 1983, Welch and McArthur 1986). The purpose of this study was to further examine the preference displayed by mule deer (Odocoileus hemionus hemionus) and elk (Cervus elaphus nelsoni) for sagebrush taxa. The taxa studied were basin big sagebrush (Artemisia tridentata Nutt. ssp. tridentata), Wyoming big sagebrush (A.t. ssp. wyomingensis Beetle and Young), mountain big sagebrush (A.t. ssp. vaseyana [Rydb.] Beetle), and black sagebrush (A. nova Nels.). The objective was to establish possible preferences by wild mule deer and elk for the 4 taxa over 10 winters of varying severity. This would avoid conclusions from anomalies that can occur for shorter periods or with small numbers of tame animals (Bartmann 1982). Therefore, the hypothesis that 4 sagebrush taxa are equally utilized as forage by mule deer and elk on winter range was tested each year at 2 sites over a 10 year period under natural conditions.

\section{Methods}

\section{Study Area}

The study was conducted within the Gallatin National Forest near Gardiner, Montana. The area is an important part of the Northern Yellowstone Winter Range for mule deer and elk and is considered by Houston (1982) and Farnes (1991) to be the most critical part of this important range. Fortunately no other ungulates occur on the portion of this important range where the study was conducted. Therefore, all browsing was from the 2 ungulates observed browsing sagebrush taxa, mule deer and elk. Two sites approximately $3 \mathrm{~km}$ apart were studied. Elevation at the 2 study sites is $1,950 \mathrm{~m}$. Average annual precipitation is $412 \mathrm{~mm}$, half of which is received as snow. Vegetative composition on the area is typical of near pristine sagebrush-grass habitat types (Mueggler and Stewart 1980, Wambolt and McNeal 1987) with an overstory of basin big sagebrush, Wyoming big sagebrush, mountain big sagebrush, and black sagebrush, and an understory dominated by bluebunch wheatgrass (Agropyron spicatum [Rydb.] Scribn.) and Idaho fescue (Festuca idahoensis Elmer). The Mollisol soils from granite and limestone have been strongly influenced by glacial scouring, morainal deposition, and outwash sediments (Wambolt and McNeal 1987). A mosaic of microsites created by these processes has nearly equal quantities of the 4 sagebrush taxa intermixed as a natural cafeteria for foraging mule deer and elk at the 2 sampling locations. 


\section{Sampling and Analysis}

To evaluate the preference of mule deer and elk, their browsing use on the 4 sagebrush taxa was measured on winter range. Sampling was conducted within two $30 \times 60 \mathrm{~m}$ browse cafeterias. Within each browse cafeteria, eight $1 \times 30 \mathrm{~m}$ belt transects were located parallel to each other at $8.6 \mathrm{~m}$ intervals. Sagebrush plants within the belt transects were identified by taxon and used throughout the study to sample winter utilization.

The typical sagebrush leader at the 2 study sites had a very twisted form, probably largely due to historically high levels of browsing. Thus, it was not possible to accurately measure the length of an adequate sample of leaders before and after browsing. Because determining relative preference of browsing animals for the 4 sagebrush taxa was the main objective of this study I compared the proportion of leaders browsed among the taxa. This method allowed an adequate sample from the gnarled crowns of the shrubs. Guenther (1989) found that in bitterbrush (Purshia tridentata [Pursh] D.C.) the number of browsed leaders was highly correlated $(r=0.94, P \leq 0.0001)$ to total utilization obtained by measuring leader lengths. The proportion of bitterbrush leaders browsed adequately predicted ( $\pm 10 \%$ ) percentage of leaders removed by browsing at 18 study sites. The relatively short leaders of sagebrush compared to bitterbrush should insure the 2 methods would result in closer results for sagebrush than Guenther (1989) obtained for bitterbrush.

Preceding the winter use period each autumn between 1982 and 1991 , a total of approximately 2,500 available leaders were tagged on 244 plants. Leaders were selected randomly from predetermined portions of each plant to insure all parts of the plants were sampled. These leaders were then re-examined the following springs between 1983 and 1992 to determine how many leaders had been browsed. By this method the percentage of total leaders browsed was determined each year after winter browsing.

In the spring of 1992 ocular estimates of the percentage of dead crown canopy in the 4 sagebrush taxa were made. Estimates were rounded to the nearest $5 \%$. Plants that died during the study, but before the spring of 1992 were not included in this estimate. However, records for the 10 year period were examined to determine the number of each taxon that had died during the study. The percentage of dead crown on mountain big sagebrush was related to mean browsing over the 10 year study by correlation (Snedecor and Cochran 1980).

Mule deer feces were sampled early each spring at the 2 cafeterias to determine winter diet composition. Each sample was a composite of 10 mule deer pellet groups. The samples were sent to the Composition Analysis Laboratory at Colorado State University for diet determination using microhistological techniques (Sparks and Malechek 1968). Twenty fields per slide were read from 5 slides per sample.

A 1-way ANOVA with taxon as the factor was conducted each year individually for the 2 sites. This avoided year and location effects that could confuse the results. The observations in the ANOVA are a transformation on the proportion of utilized leaders. Because the proportions are based on relatively small sample sizes, a variance stabilizing arcsin transformation was used (Snedecor and Cochran 1980, Steel and Torrie 1980). This transformation is not used to remove inequalities in variance, but is used when the variation is purely binomial, often arising from unequal denominators. The Least Significant Difference (LSD) method $(\mathrm{P} \leq 0.05)$ protected by a prior $F$-test $(\mathrm{P} \leq 0.05)$ was used for comparing treatment means (Snedecor and Cochran 1980).
The number of elk harvested as recorded by the Montana Department of Fish, Wildlife, and Parks during Montana's special late hunting season in the area that includes the study sites was used as a proxy variable for winter severity. A combination of weather conditions influence the ability of elk to forage on the portion of the Northern Yellowstone Winter Range within the security of Yellowstone National Park that is adjacent to the study area. When snow conditions force the elk to leave the park they enter the area where the study sites are located. This results in both an increased elk harvest and increased utilization of sagebrush taxa from the presence of more elk. Unfortunately, the Gardiner and Mammoth weather stations have much missing data during the study period for total precipitation, temperature, and snow depths. Thus, in lieu of adequate weather data elk harvest is likely the best index of winter severity for the study area. Therefore, correlations (Snedecor and Cochran 1980) were made for elk harvest and sagebrush taxa leader utilization. Correlations were also made for elk harvest and indices of winter severity for the first 8 years of this study. The indices were developed by Farnes (1991) and include minimum temperatures, snow water equivalents, and precipitation for the previous June and July which is related to winter forage. Farnes' (1991) indices estimated the previously mentioned missing weather values from adjacent climatological stations.

\section{Results and Discussion}

Mule deer and elk did browse very substantial amounts of the 4 sagebrush taxa collectively. The percentage of sagebrush leaders utilized during a given winter was as high as $91 \%$ for mountain big sagebrush (Table 1) despite the below average snowfall that prevailed over the 10 year study. During most winters, mule deer

Table 1. Percent of sagebrush leaders utilized during winter by taxon, year, and study site.

\begin{tabular}{|c|c|c|c|c|c|}
\hline Year & Site & $\begin{array}{c}\text { Mountain } \\
\text { Big } \\
\text { Sagebrush }\end{array}$ & $\begin{array}{c}\text { Wyoming } \\
\text { Big } \\
\text { Sagebrush }\end{array}$ & $\begin{array}{c}\text { Basin } \\
\text { Big } \\
\text { Sagebrush }\end{array}$ & $\begin{array}{c}\text { Black } \\
\text { Sagebrush }\end{array}$ \\
\hline & \multicolumn{5}{|c|}{$-----------(\%)------------$} \\
\hline 1982-83 & $\begin{array}{l}1 \\
2\end{array}$ & $\begin{array}{l}53^{\mathrm{a}} \\
52^{\mathrm{a}}\end{array}$ & $\begin{array}{l}29^{b} \\
24^{b}\end{array}$ & $\begin{array}{l}25^{b c} \\
19^{b}\end{array}$ & $\begin{array}{l}7^{c} \\
8^{b}\end{array}$ \\
\hline 1983-84 & $\begin{array}{l}1 \\
2\end{array}$ & $\begin{array}{l}90^{\mathrm{a}} \\
84^{\mathrm{a}}\end{array}$ & $\begin{array}{l}80^{\mathrm{b}} \\
78^{\mathrm{ab}}\end{array}$ & $\begin{array}{l}71^{b} \\
64^{b}\end{array}$ & $\begin{array}{l}31^{c} \\
66^{b}\end{array}$ \\
\hline 1984-85 & $\begin{array}{l}1 \\
2\end{array}$ & $\begin{array}{l}48^{\mathrm{a}} \\
39^{\mathrm{a}}\end{array}$ & $\begin{array}{l}20^{\mathrm{b}} \\
21^{\mathrm{b}}\end{array}$ & $\begin{array}{c}15^{b c} \\
7^{c}\end{array}$ & $\begin{array}{r}4^{c} \\
23^{b}\end{array}$ \\
\hline 1985-86 & $\begin{array}{l}1 \\
2\end{array}$ & $\begin{array}{l}59^{\mathrm{a}} \\
36^{\mathrm{a}}\end{array}$ & $\begin{array}{l}57^{\mathrm{ab}} \\
32^{\mathrm{a}}\end{array}$ & $\begin{array}{l}48^{b} \\
14^{b}\end{array}$ & $\begin{array}{l}7^{c} \\
5^{b}\end{array}$ \\
\hline $1986-87$ & $\begin{array}{l}1 \\
2\end{array}$ & $\begin{array}{l}50^{\mathrm{a}} \\
49^{\mathrm{a}}\end{array}$ & $\begin{array}{l}38^{\mathrm{b}} \\
37^{\mathrm{b}}\end{array}$ & $\begin{array}{r}21^{\mathrm{c}} \\
5^{\mathrm{c}}\end{array}$ & $\begin{array}{l}5^{d} \\
9^{c}\end{array}$ \\
\hline $1987-88$ & $\begin{array}{l}1 \\
2\end{array}$ & $\begin{array}{l}65^{\mathrm{a}} \\
50^{\mathrm{a}}\end{array}$ & $\begin{array}{l}54^{\mathrm{a}} \\
35^{\mathrm{b}}\end{array}$ & $\begin{array}{l}51^{\mathrm{a}} \\
19^{\mathrm{bc}}\end{array}$ & $\begin{array}{l}8^{b} \\
9^{c}\end{array}$ \\
\hline 1988-89 & $\begin{array}{l}1 \\
2\end{array}$ & $\begin{array}{l}66^{\mathrm{a}} \\
72^{\mathrm{a}}\end{array}$ & $\begin{array}{l}44^{b} \\
43^{b}\end{array}$ & $\begin{array}{l}53^{\mathrm{ab}} \\
35^{\mathrm{b}}\end{array}$ & $\begin{array}{l}16^{c} \\
28^{b}\end{array}$ \\
\hline $1989-90$ & $\begin{array}{l}1 \\
2\end{array}$ & $\begin{array}{l}35^{\mathrm{a}} \\
21^{\mathrm{a}}\end{array}$ & $\begin{array}{r}11^{\mathrm{b}} \\
2^{\mathrm{b}}\end{array}$ & $\begin{array}{c}15^{b} \\
4^{b}\end{array}$ & $\begin{array}{l}1^{c} \\
3^{b}\end{array}$ \\
\hline $1990-91$ & $\begin{array}{l}1 \\
2\end{array}$ & $\begin{array}{l}33^{\mathrm{a}} \\
46^{\mathrm{a}}\end{array}$ & $\begin{array}{l}11^{b c} \\
21^{b}\end{array}$ & $\begin{array}{r}15^{b} \\
8^{b}\end{array}$ & $\begin{array}{l}2^{c} \\
9^{b}\end{array}$ \\
\hline $1991-92$ & $\begin{array}{l}1 \\
2\end{array}$ & $\begin{array}{l}83^{a} \\
91^{a}\end{array}$ & $\begin{array}{l}48^{b} \\
86^{a}\end{array}$ & $\begin{array}{l}67^{b} \\
49^{\mathrm{b}}\end{array}$ & $\begin{array}{l}15^{\mathrm{c}} \\
84^{\mathrm{a}}\end{array}$ \\
\hline
\end{tabular}

Means among taxa differ $(\mathrm{P} \leq 0.05)$ within site and date when followed by a different letter. 
and elk displayed distinct preferences among the 4 taxa (Table 1). Mule deer and elk preferred the 4 taxa in decreasing amounts in the following order: mountain big sagebrush, Wyoming big sagebrush, basin big sagebrush, and black sagebrush.

Twenty utilization percentages for each taxon $(2$ sites $\times 10$ years) are presented in Table 1. All 20 utilization percentages for mountain big sagebrush were greater than for any other taxon on a given year with an average of $56.1 \%$ of leaders browsed and 16 were significantly $(\mathrm{P}<0.05)$ greater than for Wyoming big sagebrush, the second most preferred taxon with an average of $38.6 \%$. The preference found for Wyoming big sagebrush over basin big sagebrush with an average of $30.3 \%$ was not as great. Although Wyoming big sagebrush had a numerically higher utilization percentage 15 times, only 5 were significantly greater. Basin big sagebrush was found to have a higher percentage utilization figure than the least preferred taxon, black sagebrush, 15 times, with 8 significantly greater. Black sagebrush averaged $17.0 \%$ of its leaders browsed. During the winters of 1984-85 and 1991-92 the percentage of black sagebrush consumed at site 2 was significantly greater than for basin big sagebrush.

Herbivore preference for the sagebrush taxa in this study has been considered by others (Scholl et al. 1977, Sheehy and Winward 1981, Welch et al. 1981, 1983, Welch and McArthur 1986). None of the studies are in perfect agreement as to taxa use by browsing animals although mountain big sagebrush is clearly the preferred taxon. It has been demonstrated that accessions within taxa may vary greatly as to their acceptance by browsing animals (Welch et al. 1981, 1983, Welch and McArthur 1986, Welch et al. 1994). This study adds perspective by detailing long term patterns of browsing preference by wild ungulates under natural conditions.

Because the 4 taxa were all very common at the 2 study sites and equally available for browsing a preference index was not required. Schwartz and Hobbs (1985) have explained that in such situations searching time is negligible and preference indices may actually be misleading due to differences in taxa biomass or density.

Greer et al. (1970) and Houston (1982) found that the distribution and concentrations of elk within the Northern Yellowstone Winter Range vary with the climatic conditions of wind, snow, temperature, and crusting which expose or conceal forage. Accordingly, anomalies in Table 1 are explainable by weather and microsite differences. The 10 year study allowed preference determinations under a variety of winter conditions. However, none of the years were above average in severity of temperature or snow depth compared to the long term average (Farnes 1991). Because elk hunting occurs on the area from autumn through late winter, elk are not present within the study area as consistently as mule deer. This is especially true during open winters when the elk can forage within the security of Yellowstone National Park approximately $2 \mathrm{~km}$ south (Houston 1982). When elk are forced by forage limitations to leave this security the number of elk harvested during Montana's special late hunting season (mid-December through February) in the area is a good index of winter severity. This elk harvest is positively correlated to utilization of sagebrush leaders by taxon as follows: mountain big sagebrush $r=0.79(P \leq 0.01)$, Wyoming big sagebrush $r=$ $0.64(P \leq 0.05)$, basin big sagebrush $r=0.74(P \leq 0.02)$, and black sagebrush $r=0.65(P \leq 0.05)$. In general, as overall sagebrush use increased from the presence of more elk forced from higher elevations during more severe winters, differences among taxa were min- imized (Table 1). Greer et al. (1970) also learned that peaks in big sagebrush use occurred in winters with the highest elk concentrations.

Houston (1982) and Farnes (1991) also believe that winter severity dictates the number of elk in the area of my study, which they consider the most critical portion of the Northern Yellowstone Winter Range. Farnes (1991) points out that ordinary weather statistics, such as mean monthly temperature, do not address stresses imposed on wildlife during severe periods of shorter duration. Therefore, Farnes (1991) developed a scaled index of winter severity (IWS) for my study area that addresses weather effects on wildlife better than monthly means. The IWS weights 3 weather variables as follows: 1-the accumulated sum of daily minimum temperature below $-18^{\circ} \mathrm{C}(40 \%), 2$-the snow water equivalent on April 1 from snow courses in the area (40\%), and 3-precipitation for June and July of the previous summer to represent available winter forage (20\%). Farnes' (1991) IWS is only available for the first 8 years of my study. Over those 8 years the IWS is positively correlated $(r=0.75, P \leq .02)$ to the elk harvest on the area during Montana's special late hunting season.

Houston (1982) provides a historical perspective of elk seasonal distributions. He points out the efforts began in 1935 to reduce the elk herd outside the park. Despite the disproportionate reductions to the segment of the population outside the park, great variations in elk numbers leaving the park continued to occur as dictated by winter severity. Houston (1982) reported only about $5 \%$ of the elk left the park during mild winters, but nearly $60 \%$ left during severe winters. In the mild winter of 1960-61, of 8200 elk counted, only $1 \%$ left the park. During the next severe winter, 1961-62, of 5,800 elk, 55\% left the park in search of forage (Houston 1982).

The relatively heavy snow encountered on the 2 study areas as well as even greater amounts on the surrounding highlands during the winters of 1983-84 and 1991-92 resulted in well above average elk harvests and the highest utilization figures during the study. The most notable anomalies within Table 1 are the relatively high utilization levels of $66 \%$ and $84 \%$ respectively for black sagebrush at site 2 during those winters. The early snow those winters crusted over most of the other shrubs at the site. However, the black sagebrush plants were generally located on small depositional mounds situated slightly above much of the crusting and exposed to more solar radiation. This combination was apparent during those winters and aided the browsers at that location. Such use on the otherwise least utilized taxon serves to emphasize that any of the 4 taxa may serve as important dietary components of mule deer and elk. The severe winters tend to minimize preference differences in general. However, Bartmann (1982) found the greatest dietary differences between captive tame deer when snow was the deepest and he concluded that diets of wild and tame deer would differ.

Over the study mule deer winter diets at the 2 cafeterias contained identical amounts of sagebrush with an average of $52 \%$. It was not possible to distinguish among the 4 taxa with the fecal analysis procedure. Elk diets were not analyzed because late season hunts for elk leaving Yellowstone Park during the winter create fast changing movement patterns in the area. Elk move rapidly through the study area traveling between the security of Yellowstone National Park and that of higher elevations outside the park and beyond the study area. Because the sagebrush cover is greatly reduced from browsing inside the park (Wright and 
Thompson 1935, Patten 1993) compared to the study area, forage selection on the study area would not be reflected accurately due to the slow passage of forage through the ruminant system of elk. The collective elk using the study area did consume large amounts of sagebrush as evidenced by the larger amounts utilized during winters when elk were forced from the surrounding highlands due to heavy snowpack. Observations throughout the 10 year study conclude that the mule deer are not greatly influenced by the elk hunting in the area.

Many of the plants studied exhibited signs of heavy use by their browse form class and high percentage of dead crown. It appears that the percentage of dead crown in the canopies of the $3 \mathrm{big}$ sagebrush subspecies increased in relation to the levels of browsing received by the 3 taxa. The percentage of dead crown at the end of the study for mountain big sagebrush, Wyoming big sagebrush, and basin big sagebrush, averaged $58.7 \%, 45.4 \%$, and $30.1 \%$, respectively. Dead crown was measured after observing during the 10 year study that it appeared to be increasing overall. Previous to summarizing the data it was not considered that the trend of increased dead crown was related to the 3 big sagebrush taxa in proportion to the level of use they had received. It should not matter that similar data were not obtained at the beginning of the study as it is logical that the same preferences by mule deer and elk existed prior to the study. These trends with the sagebrush taxa have occurred despite excellent grass production on the site. Unfortunately, because the study objective was to determine if mule deer and elk have preferences among the 4 taxa, it was not considered necessary to sample individual plants intensively enough for subsequent analysis of a relationship between percentage dead crown and mean browsing level on a per plant basis. However, even with the low level of sampling per plant, significant correlations for mountain big sagebrush dead crown and mean browsing per plant of $r=0.42(\mathrm{P} \leq 0.03)$ and $r=0.48$ $(\mathrm{P} \leq 0.00)$ were found at sites 1 and 2 , respectively.

The level of browsing received by mountain big sagebrush at the 2 study sites (Table 1) may be above the level it can sustain over time. Thirty-five percent of all mountain big sagebrush plants died during the 10 year study, apparently killed by excessive browsing. Laycock (1967) found that heavy browsing levels in the fall often killed threetip sagebrush (Artemisia tripartita Rydb.). Bilbrough and Richards (1992) concluded sagebrush is not efficient in compensatory growth following heavy winter browsing. The loss of sagebrush in my study is not surprising as 60 years ago Wright and Thompson (1935) reported the destruction of big sagebrush within the boundaries of nearby Yellowstone National Park from heavy elk browsing. However, they noted that the destruction was confined to within the park. More recently Patten (1993) also concluded that in the vicinity of this study browsing by elk resulted in the reduction of big sagebrush.

The study area is probably more important for mule deer than elk. Mule deer are more restricted to the study area vicinity as it provides all their needs much better than surrounding terrain. Elk are able to negotiate the deeper snow at higher elevations. Although elk favor the relatively snow free conditions with easily accessible forage of the study area, they generally can survive with restricted use of the area until periods of severe weather (Greer et al. 1970, Houston 1982).

The close relationship of mule deer and sagebrush taxa is well known (Welch and McArthur 1979). The habitat requirements of mule deer are generally met in sagebrush communities. Perhaps mule deer use of sagebrush vegetative types is most commonly exhibited on winter range (Welch and McArthur 1979, Wambolt and McNeal 1987). Elk are also commonly associated with sagebrush habitat types (Wambolt and McNeal 1987). Unfortunately, some of the relationships between browsing animals and sagebrush may often be confused by ecological differences within the sagebrush complex such as the forage relationships investigated in this study.

Variation in browsing use of sagebrush taxa is the result of numerous factors operating in a variety of combinations. Certainly class of animal, environment, and season of use (Sheehy and Winward 1981) help explain differences observed in sagebrush use as a forage. In addition, previous research at this location determined that sagebrush digestibilities are influenced by the total terpenoid content of each taxon (Striby et al. 1987) while specific terpenoid compounds influence initial selection and subsequent browsing of sagebrush taxa by mule deer (Personius et al. 1987, Bray et al. 1991). Preferences determined in this study are in agreement with Personious et al. (1987) and Bray et al. (1991) when terpenoid content of the 4 taxa is considered.

Much of the confusion among natural resource managers regarding the management of sagebrush dominated rangelands originates from differing opinions regarding the utility of sagebrush taxa as forage. Management should consider that mule deer and elk and presumably other wild ungulates will use large amounts of sagebrush in their diet and during many years they will browse nearly all the current year's leaders available during the winter. However, despite a distinct preference for certain sagebrush taxa over others, these wild ungulates will use even the least preferred taxon very heavily if the others are unavailable or not present on the winter range. This is not surprising as sagebrush taxa have been proven to be highly digestible and nutritious (Welch and McArthur 1979, Striby et al. 1987, Welch and Wagstaff 1992). Sagebrush taxa may be over used and severely damaged on big game winter ranges. Management of game populations that forage on sagebrush taxa must regulate animal numbers to levels the plants can tolerate.

\section{Literature Cited}

Bartmann, R.M. 1982. Evaluation of winter food choices by tame mule deer. J. Wildl. Manage. 46:807-812.

Beetle, A.A. 1960. A study of sagebrush, the section Tridentatae of Artemisia. Univ. Wyoming Agr. Exp. Stat. Bull. 368.

Bilbrough, C.J. and J.H. Richards. 1992. Growth of sagebrush and bitterbrush following simulated winter browsing: mechanisms of tolerance. Ecol. 74:481-492.

Bray, R.O., C.L. Wambolt, and R.G. Kelsey. 1991. Influence of sagebrush terpenoids on mule deer preference J. Chem. Ecol. 17:2053-2062.

Farnes, P.E. 1991. A scaled index of winter severity, p. 135-138. Western Snow Conference, 12-15April 1991; Juneau, Alaska. Colorado State Univ. Press, Fort Collins, Colo.

Greer, K.R., J.B. Kirsch, and H.W. Yeager. 1970. Seasonal food habits of the northern Yellowstone elk herds during 1957 and 1962 1967 as determined from 793 rumen samples. Mont. Wildl. Invest. Lab. Progress Rep. No. W-83-R-12. 76p.

Guenther, G.E. 1989. Ecological relationships of bitterbrush communities on the Mount Haggin Wildlife Management Area. M.S. Thesis, Montana State. Univ. Bozeman, Mont. 73p. 
Houston, D.B. 1982. The northern Yellowstone elk. Macmillan Pub. New York, N.Y..

Laycock, W.A. 1967. How heavy grazing and protection affect sagebrush-grass ranges. J. Range Manage. 20:206-213.

Mueggler, W.F. and W.L. Stewart. 1980. Grassland and shrubland habitat types of western Montana. USDA Forest Service, Gen. Tech. Report INT-66. 154 p.

Patten, D.T. 1993. Herbivore optimization and overcompensation: does native herbivory on western rangelands support these theories? Ecol. Applications. 3:35-36.

Personious, T.L., C.L. Wambolt, J.R. Stephens, and R.G. Kelsey. 1987. Crude terpenoid influence on mule deer preference for sagebrush. J. Range Manage. 40:84-88.

Scholl, J.P., R.G. Kelsey, and F. Shafizadeh. 1977. Involvement of volatile compounds of Artemisia in browse preference by mule deer. Biochem. Syst. Ecol. 5:291-295.

Schwartz, C.C. and N.T. Hobbs. 1985. Forage and range evaluation, p. 25-51. In R.J. Hudson, and R.G. White (eds.), Bioenergetics of wild herbivores. CRC Press, Inc. Boca Raton, Fla.

Sheehy, D.P. and A.H. Winward. 1981. Relative palatability of seven Artemisia taxa to mule deer and sheep. J. Range Manage. 34:397-399.

Snedecor, G.W. and W.G. Cochran. 1980. Statistical methods. Iowa State Univ. Press, Ames, lowa.

Sparks, D.R. and J.C. Malechek. 1968. Estimating percentage dry weights in diets using a microscopic technique. J. Range Manage. 21:264-265.
Steel, R.G.D. and J.H. Torrie. 1980. Principles and procedures of statistics. McGraw-Hill Pub., New York, N.Y.

Striby, K.D., C.L. Wambolt, R.G. Kelsey, and K.M. Havstad. 1987. Crude terpenoid influence on in vitro digestibility of sagebrush. J. Range Manage. 40:244-248.

Wambolt, C.L. and A.F. McNeal. 1987. Selection of winter foraging sites by elk and mule deer. J. Environ. Manage. 25:285-291.

Welch, B.L. and E.D. McArthur. 1979. Feasibility of improving big sagebrush (Artemisia tridentata) for use on mule deer winter ranges, p. 451-457. In: J.R. Goodin, and D.K. Northington (eds.), Arid land plant resources. Texas Tech Univ., Lubbock, Tex..

Welch, B.L. and E.D. McArthur. 1986. Wintering mule deer preference for 21 accessions of big sagebrush. Great Basin Natur. 46:281-286.

WeIch, B.L. and F.J. Wagstaff. 1992. 'Hobble Creek' big sagebrush vs. antelope bitterbrush as a winter forage. J. Range Manage. 45:140-142.

Welch, B.L., S.F. Briggs, and S.A. Young. 1994. Pine Valley Ridge source: a superior selected germplasm of black sagebrush. USDA For. Ser. Res. Paper INT-RP-474.

Welch, B.L., E.D. McArthur, and J.N. Davis. 1981. Differential preference of wintering mule deer for accessions of big sagebrush and for black sagebrush. J. Range Manage. 34:409-411.

Welch, B.L., E.D. McArthur, and J.N. Davis. 1983. Mule deer preference and monoterpenoids (essential oils). J. Range Manage. 36:485-487.

Wright, G.M. and B.H. Thompson. 1935. Fauna of the National Parks of the United States: wildlife management in the national parks. Fauna Series No. 2. U.S. Govt. Printing Office. Wash., D.C.

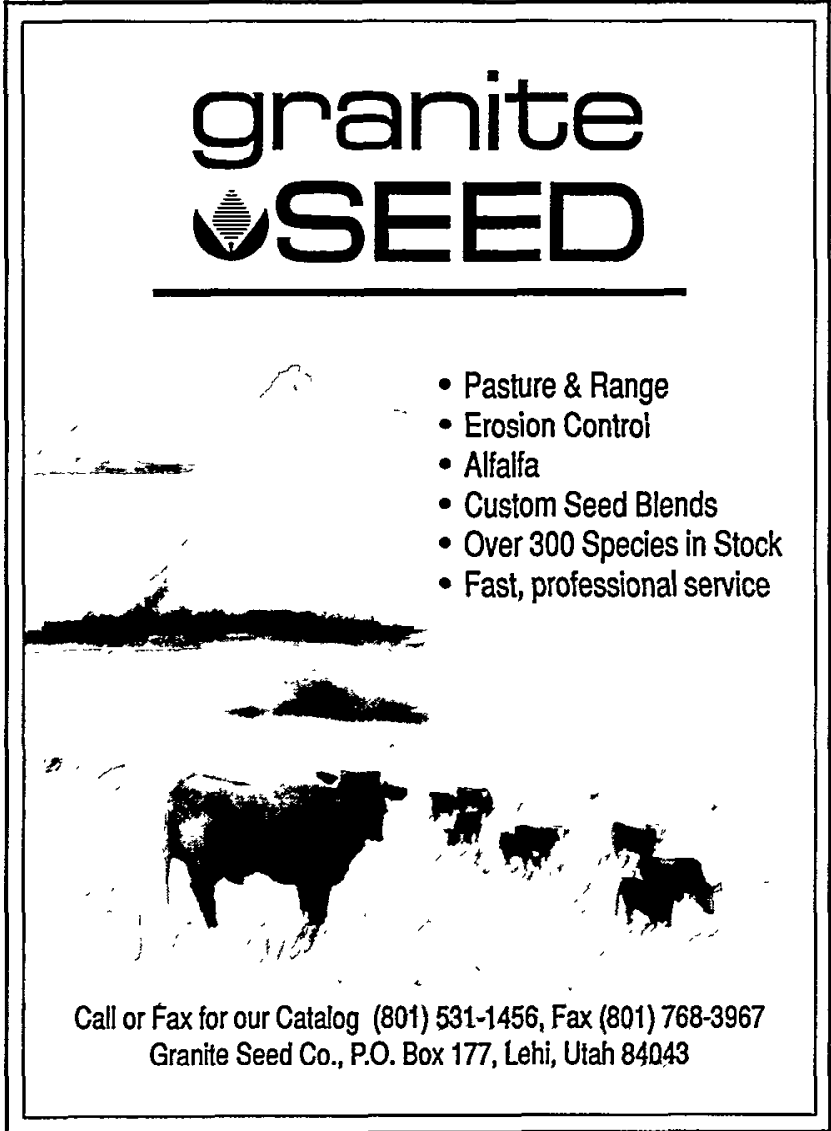

